\title{
PERBEDAAN EFEKTIFITAS TERAPI MURROTAL DENGAN KOMPRES DINGIN TERHADAP RESPON NYERI PASIEN POST OPERASI LAPARATOMI DI RUMAH SAKIT ISLAM (RSI) FATIMAH CILACAP
}

\author{
Suko Pranowo*, Asditya Kesuma Dharma, Kasron \\ Universitas Al-Irsyad Cilacap, \\ *e-mail: supra74sukopranowo@gmail.com
}

\begin{tabular}{|c|c|}
\hline & Abstract \\
\hline $\begin{array}{l}\text { Keywords: } \\
\text { kompres dingin, } \\
\text { murathal, nyeri, } \\
\text { laparatomi }\end{array}$ & $\begin{array}{l}\text { Pasien yang mengalami pembedahan atau operasi akan mengalami luka } \\
\text { insisi, sehingga sel saraf kulit rusak. Trauma jaringan akan merangsang } \\
\text { keluarnya mediator nyeri yang merangsang nyeri dan membuat kekakuan } \\
\text { otot. Tujuan penelitian ini yaitu mengetahui perbedaan efektifitas terapi } \\
\text { murrotal dengan kompres dingin terhadap respon nyeri pasien post } \\
\text { operasi laparatomi. Jenis penelitian ini adalah quasi eksperimen dengan } \\
\text { rancangan static group comparison. Jumlah sampel sebanyak } 30 \text { orang } \\
\text { yang diambil meggunakan teknik accidental samping. Tindakan berupa } \\
\text { pemberian kompres dingin dan terapi murathal. Analisa bivariat } \\
\text { menggunakan Uji } T \text { (paired dan pooled). Hasil penelitian menunjukkan } \\
\text { terdapat perbedaan respon nyeri post op laparatomi sebelum dan setelah } \\
\text { kompres dingin (pv=0.0005), terdapat perbedaan respon nyeri post op } \\
\text { laparatomi sebelum dan setelah terapi murathal (pv=0.0005), tidak } \\
\text { terdapat perbedaan respon nyeri pasien post operasi laparatomi sesudah } \\
\text { diberikan terapi murrotal dan kompres dingin. Hal tersebut berarti } \\
\text { bahwa kedua terapi memiliki efektifitas yang sama dalam menurunkan } \\
\text { respon nyeri post operasi laparatomi. Direkomendasikan untuk } \\
\text { memberikan terapi Murrotal atau terapi kompres dingin pada pasien post } \\
\text { operasi laparatomi sebagai terapi komplementer dalam menangani nyeri } \\
\text { pada pasien post operasi laparatomi. }\end{array}$ \\
\hline
\end{tabular}

\section{PENDAHULUAN}

World Health Organization (WHO) menguraikan pasien laparatomi di dunia meningkat setiap tahunnya sebesar $10 \%$. Angka jumlah pasien laparatomi mencapai peningkatan yang signifikan. Pada tahun 2018 laparatomi menempati peringkat ke 5, tercatat jumlah keseluruhan tindakan operasi terdapat terdapat 1,2 juta jiwa dan diperkirakan $42 \%$ diantaranya merupakan tindakan pembedahan laparatomi (Anwar et al., 2020).
Pasien yang mengalami pembedahan atau operasi akan mengalami luka insisi, sehingga sel saraf kulit rusak. Trauma jaringan akan merangsang terbentuknya zat kimia seperti : bradikinin, serotinin, histain, dan enzim proteotik, yang merangsang nyeri dan membuat kekakuan otot. Sinyal nyeri dari daerah yang terluka berjalan sebagai impuls elektrokimia di sepanjang saraf kebagian dorsal spinal cord. Pesan kemudian dihantarkan ke saraf perifer tubuh sehingga terjadi nyeri sebar (Anwar et al., 2020). 
Hasil penelitian (Amelia \& Saputri, 2020) menunjukan rata-rata skala nyeri pasien post operasi laparatomi adalah 4,70. Hasil penelitian (Marliyana, 2018) menunjukkan bahwa rata-rata skala nyeri pasien post operasi laparatomi yaitu 9,25. Sedangkan penelitian (Anwar et al., 2020) menunjukkan bahwa rata-rata skala nyeri pasien post operasi laparatomi yaitu 8,50.

Dampak nyeri post laparatomi mempunyai kecenderungan tidak bisa melakukan mobilisasi, serta tidak bisa berkomunikasi dengan baik dengan perawat, bahkan bisa melakukan tindakan percobaan bunuh diri dikarenakan tidak tahannya mereka dengan rasa nyeri yang diderita (Amelia \& Saputri, 2020). Dampak tersebut perlu dicegah dengan upaya penatalaksanaan nyeri yang dapat dilakukan secara farmakologi dan non farmakologi. Terapi farmakologi dilakukan dengan memberikan obat-obatan analgetik sedangkan terapi non farmakologi dapat dilakukan dengan bermacam cara antara lain stimulasi dan masase, kompres dingin dan hangat, distraksi, teknik relaksasi, dan hipnotis (Smeltzer \& Bare, 2017).

Pemberian obat analgesik juga memiliki efek samping seperti mual, muntah dan ketergantungan, sehingga pemberian terapi komplementer untuk mengatasi nyeri post operasi secara berkesinambungan sangat dibutuhkan pada kondisi ini (Sodikin, 2012). Sehingga penatalaksanaan nonfarmakologis dapat diterapkan sebagai pengganti intervensi atau terapi komplementer dalam menurunkan intensitas nyeri.

Salah satu terapi komplementer untuk mengatasi nyeri adalah kompres dingin. Terapi kompres dingin termasuk dalam salah satu terapi manipulatif yaitu cryotherapy. Kompres dingin adalah suatu metode dalam penggunaan suhu rendah setempat yang dapat menimbulkan beberapa efek fisiologis. Terapi dingin diperkirakan menimbulkan efek analgetik dengan memperlambat kecepatan hantaran saraf sehingga impuls nyeri yang mencapai otak lebih sedikit (Kristanto \& Arofiati, 2016).

Hasil penelitian (Talu et al., 2018) menunjukkan sebelum kompres dingin hampir seluruhnya dikategorikan nyeri berat sebanyak 19 orang $(95,0 \%)$, sesudah kompres dingin sebagian besar responden dikategorikan nyeri ringan sebanyak 11 orang $(55,5 \%)$. Hasil penelitian (Iryanto, 2019) menunjukkan bahwa pasien post operasi mayor sebelum diberikan kombinasi terapi kompres dingin dan terapi Murrotal mempunyai skala nyeri rata-rata 8,2 , sesudah diberikan intervensi mempunyai skala nyeri rata-rata 5,73 , hasil uji statistik menunjukkan ada perbedaan skala nyeri pasien post operasi mayor pada kelompok intervensi sebelum dan setelah diberikan kombinasi terapi kompres dingin dan terapi Murrotal melalui media audio ( $\mathrm{p}$ $=0,000, \alpha=0,05)$.

Kompres dingin dapat menyebabkan vasokonstriksi sehingga menimbulkan efek baal atau mati rasa pada kulit. Suhu dingin menghentikan metabolisme sel dan menghambat gerbang kanal natrium pada neurotransmiter ujung saraf bebas sehingga menghambat penjalaran impuls nyeri ke otak. Kompres dingin menghambat nyeri pada proses transduksi di permukaan kulit dengan cara menghentikan potensial aksi pada reseptor penerima rangsangan nyeri sehingga tidak menghasilkan impuls listrik. Oleh karena itu, tidak terjadi proses transmisi, modulasi dan persepsi pada rangkaian serabut saraf yang khusus bekerja mengolah rangsang nyeri (Herrera et al., 2010).

Terapi komplementer lain yang dapat digunakan untuk mengatasi nyeri adalah mind-body therapy. Terapi murotal termasuk dalam mind-body therapy. Penelitian yang dilakukan Ahmad Al-Qadhi, dimana hasil penelitian tersebut menunjukkan hasil positif bahwa mendengarkan ayat suci Al- Quran memiliki pengaruh yang signifikan dalam menurunkan ketegangan urat saraf reflektif (Aryanti \& Bahtiar, 2015). 
Penatalaksanaan nyeri akut pasien post operasi melalui bacaan Al-Quran dapat menstimulasi neuropeptide dan stimulasi pengeluaran opioid endogen natural. Keterlibatan pasien post operasi dalam mengatasi nyeri secara aktif melalui rangsangan bacaan Al-Quran dapat menurunkan ketegangan sistem saraf dan membuat relaksasi. Pemberian terapi bacaan Al-Quran berdampak pada ketenangan, perubahan sel-sel tubuh dan menjadi modalitas pilihan dalam memicu opioid endogen serta sebagai kesembuhan penyakit jasmani dan rohani (Sodikin, 2012).

Hasil penelitian (Sodikin, 2012) menunjukkan ada perbedaan skala nyeri sebelum dan sesudah Terapi Bacaan AlQuran (TBA), dimana sebelum pemberian terapi murotal Al-Quran rata-rata skala nyeri yaitu 4,86 dan setelah pemberian tindakan terapi murotal Al-Quran terjadi penurunan skala nyeri menjadi 3,55.

Terapi murrotal Al-Quran tidak mempunyai dampak negatif dan kekurangan. Hanya ditemukan keterbatasan dari terapi murrotal yaitu penggunaannya terbatas pada komunitas muslim, artinya hanya bisa diterapkan pada pasien yang beragama Islam, dan yang tidak mempunyai gangguan pendengaran (Geraldina, 2017)(Geraldina, 2017).

Berdasarkan data dari RSI Fatimah Cilacap didapatkan pada tahun 2020 jumlah pasien operasi laparatomi ada sebanyak 270 orang, dengan rincian apendiksitis sebanyak 147 orang, ileus sebanyak 53 orang dan hernia ada sebanyak 70 orang. Berdasarkan wawancara terhadap perawat di ruang bedah RSI Fatimah Cilacap, diketahui bahwa terapi non farmakologi yang biasa digunakan untuk menurunkan nyeri pasien post operasi laparatomi adalah dengan teknik relaksasi nafas dalam tetapi tidak semua perawat memberikan terapi tersebut, belum pernah dilakukan terapi murotal dan kompres dingin. Hasil wawancara terhadap 5 pasien post operasi laparatomi, didapatkan 2 dari 5 pasien menyatakan merasakan sakit dan nyeri yang cukup berat pada daerah luka jahitan, 2 orang menyatakan sakit tetapi masih dalam batas wajar dan 1 orang menyatakan merasakan nyeri yang kadang nggak bisa ditahan.

Adanya berbagai perbedaan yang ada antara dua tindakan terapi non farmakologis untuk menurunkan skala nyeri post operasi laparatomi, terutama dari segi konsep-konsep dasar, waktu, cara, dampak dan manfaat serta aspek lainnya dari masing-masing tindakan, maka diperlukan uji beda efektivitas kedua tindakan. Sehingga dapat direkomendasikan tindakan non farmakologis yang efektif digunakan untuk menurunkan skala nyeri post operasi laparatomi.

Rumusan masalah penelitian yaitu "Bagaimanakah perbedaan efektifitas terapi murrotal dengan kompres dingin terhadap respon nyeri pasien post operasi laparatomi di Rumah Sakit Islam (RSI) Fatimah Cilacap ?"

Tujuan penelitian ini yaitu mengetahui perbedaan efektifitas terapi murrotal dengan kompres dingin terhadap respon nyeri pasien post operasi laparatomi di Rumah Sakit Islam (RSI) Fatimah Cilacap.

Manfaat penelitian yaitu dapat digunakan dalam pengembangan asuhan keperawatan pada pasien post operasi laparatomi dalam menurunkan tingkat nyeri dengan mengkombinasikan tindakan farmakologi dan non farmakologi khususnya terapi murrotal dan kompres dingin.

\section{METODE}

Metode berisi penjelasan tentang jenis penelitian, bahan dan alat yang digunakan, waktu, tempat, teknik, dan rancangan percobaan. Metode harus dijelaskan selengkap mungkin agar dapat dilakukan uji ulang pada peneliti selanjutnya.

Jenis penelitian ini adalah quasi eksperimen dengan rancangan static group comparison. Jumlah sampel sebanyak 30 orang yang diambil meggunakan teknik accidental samping, dengan kriteria inklusi 
yaitu: pasien post op laparatomi hari-0, laparatomi yang pertama, berusia dewaasa awal (20-40 th), suku Jawa, TTV stabil, tidak mengalami gangguan pendengaran, skala nyeri 3-10, ditunggu oleh keluarganya, dan telah mendapatkan obat analgesik selama 6 jam sebelum intervensi. Penelitian dilaksanakan di Ruang Rawat Inap Bedah RSI Fatimah cilacap pada bulan Maret sampai dengan April 2021.

Pengambilan data skala nyeri post laparatomi menggunakan instrumen Numeric Rating Scale. Intervensi diberikan setelah 6 jam diberikan obat analgesik sebagai terapi medis standar di Rumah Sakit. Tindakan kompres dingin dilakukan dengan kantung es yang diisi es/air es dengan suhu $10-15^{\circ} \mathrm{C}$ diberikan selama 510 menit dengan waktu istirahat 5 menit. Tindakan pemberian bacaan murathal surat Ar-Rahmaan dilakukan menggunakan media audio/MP3 player, dengan qari Syaikh Al-Ghomidy, yang diberikan selama 10 - 15 menit sebanyak 3 kali putaran, dan diberikan waktu istirahat setelah bacaan selesai selama 5 menit.

Analisa data dilakukan uji normalitas data menggunakan Saphiro Wilk, uji bivariat menggunakan Paired Sampel T Test dan Independent Sample T Test.

\section{HASIL}

Hasil penelitian dapat dijelaskan sebagai berikut:

Tabel 1.

Karakteristik Umur Pasien post operasi laparatomi yang Diberikan Terapi Murrotal dan Kompres Dingin di RSI Fatimah Cilacap

\begin{tabular}{lcccc}
\hline \multicolumn{1}{c}{ Umur } & $\mathrm{N}$ & Mean & SD & Min-Max \\
\hline $\begin{array}{l}\text { Terapi } \\
\text { Murotal }\end{array}$ & 15 & 32,13 & 10,280 & $20-40$ \\
$\begin{array}{l}\text { Kompres } \\
\text { Dingin }\end{array}$ & 15 & 36,07 & 9,764 & $22-64$ \\
\hline
\end{tabular}

Tabel 1 menunjukkan bahwa berdasarkan umur untuk kelompok terapi murrotal ratarata umur pasien post operasi laparatomi adalah 32,13 sedangkan pada kelompok kompres dingin rata-rata umur pasien post operasi laparatomi 36,07. Hal ini berarti bahwa umur kedua kelompok berada pada kategori Dewasa Muda.
Tabel 2.

Tingkat Pendidikan dan Pekerjaan Pasien post operasi laparatomi yang diberikan Terapi murrotal dan Kompres Dingin Berdasarkan Tingkat Pendidikan dan Pekerjaan di RSI Fatimah Cilacap

\begin{tabular}{clcccc}
\hline \multirow{2}{*}{ No. Karakteristik } & \multicolumn{2}{c}{$\begin{array}{c}\text { Terapi } \\
\text { Murrotal }\end{array}$} & \multicolumn{2}{c}{$\begin{array}{c}\text { Kompres } \\
\text { Dingin }\end{array}$} \\
\cline { 3 - 6 } & & f & \% & f & \% \\
\hline 1. & Pendidikan & & & & \\
& SD & 2 & 13,3 & 2 & 13,3 \\
& SMP & 3 & 20 & 2 & 13,3 \\
SMA & 6 & 40 & 8 & 53,3 \\
S1 & 4 & 26,7 & 2 & 13,3 \\
& S2 & 0 & 0 & 1 & 6,7 \\
\hline 2. & Pekerjaan & & & & \\
& Wiraswasta & 6 & 40 & 4 & 26,7 \\
& Swasta & 4 & 26,7 & 4 & 26,7 \\
& Buruh & 1 & 6,7 & 0 & 0 \\
PNS & 1 & 6,7 & 0 & 0 \\
IRT & 3 & 20 & 7 & 46,7 \\
\hline
\end{tabular}

Berdasarkan tabel 2 diketahui bahwa sebagian besar pasien post operasi laparatomi di RSI Fatimah Cilacap baik pada kelompok yang diberikan terapi murrotal maupun kompres dingin berpendidikan lulus SMA. Paling banyak pasien kelompok terapi murratal memiliki pekerjaan sebagai wiraswasta (40\%), kelompok terapi kompres dingin bekerja sebagai IRT $(46,7 \%)$.

Tabel 3.

Hasil Analisis Univariat

\begin{tabular}{lcccc}
\hline \multicolumn{2}{c}{ Kelompok } & N & Mean \pm SD & Min-Max \\
\hline Terapi & Pre & 15 & $6,26 \pm 1,03$ & $5-8$ \\
Murotal & Post & & $4,66 \pm 1,05$ & $3-6$ \\
Kompres & Pre & 15 & $6,33 \pm 1,05$ & $5-8$ \\
Dingin & Post & & $4,80 \pm 137$ & $3-7$ \\
\hline
\end{tabular}

Tabel 3. menunjukkan bahwa dari 15 pasien post operasi laparatomi di RSI Fatimah Cilacap sebelum diberikan terapi murrotal mempunyai respon nyeri rata-rata 6,26 dan sesudah diberikan terapi murrotal mempunyai respon nyeri rata-rata 4.66. Sebelum diberikan terapi kompres dingin mempunyai respon nyeri rata-rata 6,33 dan sesudah diberikan terapi kompres dingin mempunyai respon nyeri rata-rata 4,8 .

Tabel 4 menunjukkan bahwa data respon nyeri kedua kelompok terdistribusi normal, sehingga pengujian menggunakan uji parametrik, yaitu uji t. 
Tabel 4

Hasil uji normalitas data menggunakan ShapiroWilk $(\mathrm{n}=15)$

\begin{tabular}{lccccc}
\hline \multicolumn{1}{c}{$\begin{array}{c}\text { Respon } \\
\text { nyeri }\end{array}$} & Mean & SD & $\mathbf{Z}$ & $\mathbf{p v}$ & $\boldsymbol{\alpha}$ \\
\hline $\begin{array}{l}\text { Terapi } \\
\text { murrotal }^{\text {a }}\end{array}$ & 6,26 & 1,032 & 0,885 & $0,056^{\mathrm{c}}$ & 0,05 \\
$\begin{array}{l}\text { Kompres } \\
\text { dingin }^{\mathrm{a}}\end{array}$ & 6,33 & 1,046 & 0,882 & $0,052^{\mathrm{c}}$ & \\
$\begin{array}{l}\text { Terapi } \\
\text { murrotal }^{\mathrm{b}}\end{array}$ & 4,66 & 1,046 & 0,882 & $0,052^{\mathrm{c}}$ & \\
$\begin{array}{l}\text { Kompres } \\
\text { dingin }^{\mathrm{b}}\end{array}$ & 4,80 & 1,373 & 0,913 & $0,149^{\mathrm{c}}$ & \\
\hline a pre test, $^{\mathrm{b}}$ post test, & & & & \\
\end{tabular}

Tabel 5.

Perbedaan Respon Nyeri Pasien Post Operasi Laparatomi di RSI Fatimah Cilacap Sebelum dan Sesudah Diberikan Terapi Murrotal $(n=15)$

\begin{tabular}{llccc}
\hline $\begin{array}{c}\text { Respon } \\
\text { nyeri }\end{array}$ & Mean \pm SD & $\begin{array}{c}\text { Perbedaan } \\
\pm \mathbf{S D}\end{array}$ & t & Pv \\
\hline Pre Test & $6,266 \pm 1,032$ & 1,60 & 4,773 & $0,0005^{\text {a }}$ \\
Post Test & $4,666 \pm 1,046$ & $\pm 1,298$ & & \\
\hline a Paired T-Test , signifikan & & &
\end{tabular}

Tabel 5 menunjukkan bahwa rata-rata respon nyeri sebelum diberikan terapi murotal adalah 6,266, sesudah diberikan terapi murrotal didapatkan rata-rata respon nyeri adalah 4,666 serta terlihat rata-rata respon nyeri sesudah diberikan terapi murrotal turun sebesar 1,60. Hasil uji beda dengan $p$ value $=0,0005$ dan $\alpha=0,05$ sehingga disimpulkan terdapat perbedaan respon nyeri pasien post operasi laparatomi di RSI Fatimah Cilacap sebelum dan sesudah diberikan terapi murrotal.

Tabel 6

Perbedaan Respon Nyeri Pasien Post Operasi Laparatomi di RSI Fatimah Cilacap Sebelum dan Sesudah Diberikan Terapi Kompres Dingin $(n=15)$

\begin{tabular}{lllll}
\hline $\begin{array}{c}\text { Respon } \\
\text { nyeri }\end{array}$ & Mean \pm SD & $\begin{array}{c}\text { Perbedaan } \\
\mathbf{\mathbf { S } D}\end{array}$ & $\mathbf{T}$ & Pv \\
\hline Pre Test & $6,333 \pm 1,046$ & 1,53 & 7,122 & $0,0005^{\mathrm{a}}$ \\
Post Test & $4,8 \pm 1,373$ & $\pm 0,833$ & & \\
\hline a Paired T-Test, Signifikan & &
\end{tabular}

Tabel 6 menunjukkan bahwa rata-rata respon nyeri sebelum diberikan terapi kompres dingin adalah 6,333 dan sesudah diberikan terapi kompres dingin didapatkan rata-rata respon nyeri adalah 4,8 serta terlihat rata-rata respon nyeri sesudah diberikan terapi kompres dingin turun sebesar 1,533. Hasil uji beda dengan $p$ value $=0,0005$ dan $\alpha=0,05$ sehingga disimpulkan terdapat perbedaan respon nyeri pasien post operasi laparatomi di RSI Fatimah Cilacap sebelum dan sesudah diberikan terapi kompres dingin.

Tabel 7

Perbedaan Respon Nyeri Pasien Post Operasi Laparatomi di Rumah Sakit Islam (RSI) Fatimah Cilacap Sebelum Diberikan Terapi Murrotal dan Kompres Dingin $(n=30)$

\begin{tabular}{|c|c|c|c|}
\hline Kelompok & $\mathbf{N}$ & Mean \pm SD & CI $(95 \%)$ \\
\hline Terapi Murrotal & 15 & $6,26 \pm 1,032$ & 0,066 \\
\hline Kompres Dingin & 15 & $6,33 \pm 1,046$ & $(-0,71-0,84)$ \\
\hline \multicolumn{4}{|c|}{$p$ value $=0,852$} \\
\hline
\end{tabular}

Tabel 6 menunjukkan bahwa perbedaan rata-rata respon nyeri sebelum diberikan terapi murrotal dan kompres dingin sebesar 0,666 . Hasil uji statistik didapatkan $p$ value sebesar $0,852(\alpha=0,05)$, sehingga dapat disimpulkan tidak terdapat perbedaan respon nyeri pasien post operasi laparatomi di Rumah Sakit Islam (RSI) Fatimah Cilacap sebelum diberikan terapi murrotal dan kompres dingin. Sehingga bisa dikatakan bahwa respon nyeri kedua kelompok berada pada tingkat yang sama.

Tabel 8

Perbedaan Respon Nyeri Pasien Post Operasi Laparatomi di Rumah Sakit Islam (RSI) Fatimah Cilacap Sesudah Diberikan Terapi Murrotal dan Kompres Dingin $(n=30)$

\begin{tabular}{lccc}
\hline \multicolumn{1}{c}{ Kelompok } & $\mathrm{N}$ & Mean \pm SD & CI $(95 \%)$ \\
\hline Terapi Murrotal & 15 & $4,66 \pm 1,373$ & 0,133 \\
Kompres Dingin & 15 & $4,80 \pm 1,046$ & $(-0,78-1,046)$ \\
\hline \multicolumn{4}{c}{$\mathrm{P}$ value $=0,251$} \\
andependent T-Test, tidak ada perbedaan
\end{tabular}

Tabel 8 menunjukkan bahwa perbedaan rata-rata respon nyeri sesudah diberikan terapi murrotal dan kompres dingin sebesar 0,133 . Hasil uji statistik didapatkan $p$ value sebesar 0,251 $(\alpha=0,05)$, maka dapat disimpulkan tidak terdapat perbedaan respon nyeri pasien post operasi laparatomi di Rumah Sakit Islam (RSI) Fatimah Cilacap sesudah diberikan terapi murrotal dan kompres dingin. Hal tersebut berarti bahwa kedua terapi memiliki efektifitas yang sama dalam menurunkan respon nyeri post operasi laparatomi. 


\section{PEMBAHASAN}

Perbedaan Respon Nyeri Pasien Post Operasi Laparatomi di Rumah Sakit Islam (RSI) Fatimah Cilacap Sebelum dan Sesudah Diberikan Terapi Murrotal

Berdasarkan hasil penelitian diketahui bahwa rata-rata respon nyeri sebelum diberikan terapi murotal adalah 6,266 dengan standar deviasi 0,032, sesudah diberikan terapi murrotal didapatkan ratarata respon nyeri adalah adalah 4,666 dengan standar deviasi 1,046 terlihat ratarata respon nyeri sesudah diberikan terapi murrotal turun sebesar 1,60. Hasil uji statistik didapatkan nilai pv sebesar 0,000, maka dapat disimpulkan terdapat perbedaan respon nyeri pasien post operasi laparatomi di RSI Fatimah Cilacap sebelum dan sesudah diberikan terapi murrotal. Hasil penelitian mendukung penelitian (Marliyana, 2018), dimana hasil analisis bivariat diketahui ada pengaruh pemberian terapi murotal Qur'an terhadap skala nyeri pasien post op laparatomi saat dilakukan perawatan luka di ruang Kutilang RS Dr.Hi. Abdoel Moeloek tahun 2017 dengan ( $p$ value $=0,000$ ).

Skala nyeri mengalami penurunan setelah diperdengarkan Murrotal al Quran dapat disebabkan karena lantunan suara murrotal dapat mengalihkan perhatian (distraksi) dan memberi efek relaks sehingga mengurangi perasaan nyeri pada pasien post operasi laparotomy. Terapi murrotal mengubah getaran suara menjadi gelombang yang ditangkap oleh tubuh, menurunkan stimuli reseptor nyeri dan otak terangsang mengeluarkan analgesik opioid natural endogen untuk memblokade nociceptor nyeri, yaitu hormon endorfin (Susanto, 2015).

Terapi murotal Al-Qur'an atau bacaan Al-Qur'an dengan keteraturan irama dan bacaan yang benar juga merupakan sebuah musik, Al-Qur'an mampu mendatangkan ketenangan dan meminimalkan kecemasan 97\% bagi mereka yang mendengarnya. Hasil ini tercatat dan terukur secara kuantitatif dan kualitatif oleh sebuah alat yang berbasis komputer. Ketenangan jiwa ini menimbulkan relaksasi bagi tubuh. Relaksasi ini mempengaruhi terbentuknya gelombang tetha pada otak dimana frekuensinya 5-8 Hz. Gelombang ini mampu mempengaruhi produksi hormon endorfin yang menghambat aktifitas trigger cell. Ketika aktifitas trigger cell dihambat, gerbang pada Substansia Gelatinosa menutup dan impuls nyeri berkurang atau sedikit ditransmisikan ke otak (Asiyah \& Istikhomah, 2019).

Membaca atau mendengarkan Al-Quran akan memberikan efek relaksasi, sehingga pembuluh darah nadi dan denyut jantung mengalami penurunan. Bagian sel tubuh yang sakit, kemudian diperdengarkan bacaan Al-Quran, akan mempengaruhi gelombang dalam tubuh dengan cara merespon suara dengan getaran-getaran sinyalnya dikirimkan ke sistem saraf pusat. Terapi bacaan Al-Quran ketika diperdengarkan pada orang atau pasien akan membawa gelombang suara dan mendorong otak untuk memproduksi zat kimia yang disebut neuropeptide. Molekul ini akan mempengaruhi reseptor-reseptor didalam tubuh sehingga hasilnya tubuh merasa nyaman (Sodikin, 2012).

\section{Perbedaan Respon Nyeri Pasien Post Operasi Laparatomi di Rumah Sakit Islam (RSI) Fatimah Cilacap Sebelum dan Sesudah Diberikan Terapi Kompres Dingin}

Berdasarkan hasil penelitian diketahui bahwa rata-rata respon nyeri sebelum diberikan terapi kompres dingin adalah 6,333 dengan standar deviasi 1,046, sesudah diberikan terapi kompres dingin didapatkan rata-rata respon nyeri adalah adalah 4,80 dengan standar deviasi 1,373 terlihat rata-rata respon nyeri sesudah diberikan terapi kompres dingin turun sebesar 1,533. Hasil uji statistik didapatkan nilai pv sebesar 0,000, maka dapat disimpulkan terdapat perbedaan respon nyeri pasien post operasi laparatomi di RSI Fatimah Cilacap sebelum dan sesudah diberikan terapi kompres dingin. Hasil penelitian mendukung penelitian (Potter et 
al., 2013) tentang Efektifitas Penggunaan Cold Pack Dibandingkan Relaksasi Nafas Dalam untuk Mengatasi Nyeri Pasca Open Reduction Internal Fixation (ORIF). Hasil uji independen t-test sebelum dan setelah dilakukan intervensi Cold Pack membuktikan bahwa terdapat penurunan skala nyeri dengan nilai p 0,000. Hasil penelitian juga mendukung penelitian (Watkins et al., 2014) diperoleh hasil adanya pengaruh Cryotherapy terhadap nyeri insisi dengan signifikansi statistik (p $=0,001<0,05)$. Hasil penelitian juga relevan dengan penelitian Pranowo, Prasetyo dan Handayani (2016) bahwa terdapat perbedaan skala nyeri yang bermakna antara sebelum pemberian kompres dingin dan setelah pemberian kompres dingin pada pasien saat kanulasi inlet akses femoralis hemodialisis ( $p$ value $=0,0001$ ).

Skala nyeri mengalami penurunan karena kompres dingin menyebabkan efek baal di kulit, sehingga dapat mengurangi nyeri. Selain itu kompres dingin dapat mengurangi peradangan dan memiliki efek analgetik dengan memperlambat kecepatan hantaran saraf sehingga impuls nyeri yang mencapai otak lebih sedikit. Kompres dingin memperlambat tingkat metabolisme sel sehingga mengurangi kerusakan jaringan. Selain itu, dapat mencegah plastisitas dan nyeri kronis dengan mengurangi sensitivitas saraf bebas, meningkatkan ambang batas nyeri dan memperlambat aktivitas sinaptik (Watkins et al., 2014).

Hal ini dapat dijelaskan karena nyeri pembedahan sedikitnya mengalami dua perubahan, pertama akibat pembedahan itu sendiri yang menyebabkan rangsangan nosiseptif dan yang kedua setelah proses pembedahan terjadi respon inflamasi pada daerah sekitar operasi, dimana terjadi pelepasan zat-zat kimia (prostaglandin, histamin, serotonin, bradikinin, dan substansi P) oleh jaringan yang rusak dan sel-sel inflamasi. Zat-zat kimia yang dilepaskan inilah yang berperan pada proses transduksi dari nyeri pada pasca pembedahan. Seiring berjalannya waktu maka proses inflamasi akan berkurang dan akan menurunkan intensitas nyeri pada paisen post operasi pada umumnya termasuk laparotomi. Pemberian kompres dingin akan mempengaruhi proses hemodinamik tubuh dengan vasokonstriksi, mengurangi aliran darah ke daerah luka sehingga menurunkan oedema, mematikan sensasi nyeri dan memperlambat proses inflamasi. Terapi dingin mengurangi suhu kulit dan otot dengan mengurangi aliran darah ke jaringan yang dingin dan mengaktifkan refleks vasokonstriktif simpatis, menyebabkan penurunan aliran darah yang diinduksi sehingga mengurangi edema dan memperlambat pengiriman mediator inflamasi (misalnya leukosit), mengurangi peradangan pada daerah yang terkena, juga mengurangi hipoksia metabolik yang berpotensi mencegah kerusakan hipoksia sekunder pada jaringan yang terluka (Malanga et al., 2015).

Terapi kompres dingin menginduksi anestesi lokal, efek tersebut disebut sebagai neurapraxia yang diinduksi dingin, dengan mengurangi ambang aktivasi nosiseptor jaringan dan kecepatan konduktor dari sinyal-sinyal yang mendasari rasa sakit. Kompres dingin berhubungan dengan efektifitas deteksi trancient receptor potencial (TRP) M8 yakni dari penurunan suhu dibawah suhu kulit hingga $10{ }^{\circ} \mathrm{C}-15$ ${ }^{\circ} \mathrm{C}$. Kerja TRPM8 juga dipengaruhi oleh aktifitas pompa ion $\mathrm{K}+$. Penurunan aktifitas kanal $\mathrm{K}+$ mengakibatkan peningkatan fraksi neuron yang berespon pada suhu dingin. Sehingga, kanal ion $\mathrm{Na}+(\mathrm{NaV})$ akan ter-inaktifasi oleh suhu dingin yang menyebabkan penurunan impuls nyeri (Putra \& Budiarta, 2017).

Perbedaan Respon Nyeri Pasien Post Operasi Laparatomi di Rumah Sakit Islam (RSI) Fatimah Cilacap Sebelum Diberikan Terapi Murrotal dan Kompres Dingin.

Berdasarkan hasil penelitian diketahui bahwa perbedaan rata-rata respon nyeri sesudah diberikan terapi murrotal dan 
kompres dingin sebesar 0,666. Hasil uji statistik didapatkan nilai pv sebesar 0,852 $(\alpha=0,05)$, maka dapat disimpulkan tidak terdapat perbedaan respon nyeri pasien post operasi laparatomi di Rumah Sakit Islam (RSI) Fatimah Cilacap sebelum diberikan terapi murrotal dan kompres dingin.

Nyeri adalah efek samping yang tidak dapat dihindari dari operasi laparotomi sebagai akibat dari peradangan lokal pada trauma jaringan akibat insisi dan menyebabkan stimulasi di sekitarnya. Selain itu nyeri terjadi sebagai akibat semakin berkurangnya efek obat analgesik yang diberikan pasca operasi. Nyeri adalah pengalaman sensori dan emosional yang tidak menyenangkan akibat dari kerusakan jaringan yang aktual dan potensial. Nyeri sangat mengganggu dan menyulitkan banyak orang dibanding suatu penyakit manapun. Nyeri diartikan sebagai sensasi ketidaknyamanan tubuh pasien post operasi yang dipersepsikan oleh jiwa, fantasi luka yang dihubungkan dengan kondisi aktual atau potensial kerusakan jaringan dan keberadaanya diketahui bila orang pernah merasakannya (Smeltzer \& Bare, 2017). Menurut (Potter et al., 2013) pasien pasca operasi seringkali mengeluh rasa nyeri, keluhan ini sebenarnya wajar karena tubuh mengalami luka dan poses penyembuhannya tidak sempurna. Nyeri yang dirasakan pasien bedah meningkat seiring dengan berkurangnya pengaruh anastesi. Secara signifikan nyeri dapat memperlambat pemulihan).

\section{Perbedaan Respon Nyeri Pasien Post Operasi Laparatomi di Rumah Sakit Islam (RSI) Fatimah Cilacap Sesudah Diberikan Terapi Murrotal dan Kompres Dingin.}

Berdasarkan hasil penelitian diketahui bahwa perbedaan rata-rata respon nyeri sesudah diberikan terapi murrotal dan kompres dingin sebesar 0,133. Hasil uji statistik didapatkan nilai pv sebesar 0,251 $(\alpha=0,05)$, maka dapat disimpulkan tidak terdapat perbedaan respon nyeri pasien post operasi laparatomi di Rumah Sakit Islam
(RSI) Fatimah Cilacap sesudah diberikan terapi murrotal dan kompres dingin.

Tidak adanya perbedaan skala nyeri setelah intervensi murrotal dan kopres dingin dapat disebabkan karena setelah efek analgesic standar (ketorolac) yang diberikan habis, kemudian diberikan terapi kompres dingin dan terapi Murrotal sehingga kedua jenis intervensi ini menurunkan tingkat nyeri secara signifikan. Hal ini menunjukkan bahwa meskipun kedua terapi ini memiliki cara yang berbeda, akan tetapi keduanya bekerja dalam menghambat transmisi nyeri. Kompres dingin dan murrotall dalam beberapa penelitian terbukti dapat menurunkan tingkat nyeri.

Murottal merupakan terapi suara dan alunan murottal seperti halnya musik merupakan salah satu bentuk distraksi karena memiliki irama dan aturan tersendiri sehingga bekerja atau berperan dalam susunan syaraf pusat dengan bekerja sesuai teori gate control yang dapat menyebabkan gerbang sumsum tulang menutup sehingga memodulasi dan mencegah input nyeri untuk masuk ke pusat otak yang lebih tinggi untuk dinterpretasikan sebagai pengalaman nyeri. Mekanisme dalam memberikan efek menurunkan nyeri dalam teori Gate Control adalah dimana impuls musik yang berkompetisi mencapai korteks serebri bersamaan dengan impuls nyeri akan berefek pada distraksi kognitif dalam inhibisi persepsi nyeri kesan yang muncul bahwa transmisi dari hal yang berpotensi sebagai impuls nyeri bisa dimodulasikan oleh "cellular gating mechanism" yang ditemukan di spinal cord (Novita, 2012).

Murottal dapat mengurangi rasa nyeri melalui mekanisme menghantarkan gelombang suara, yang akan mengubah pergerakan cairan tubuh, medan elektromagnetis pada tubuh. Perubahan ini diikuti stimulasi perubahan reseptor nyeri, dan merangsang jalur listrik di substansia grisea serebri sehingga terstimulasi neurotransmitter analgesia alamiah (endorphin, dinorphin) dan selanjutnya menekan substansi $\mathrm{P}$ sebagai penyebab 
nyeri (Sodikin, 2012). Endorfin juga sebagai ejektor dari rasa rileks dan ketenangan yang timbul, midbrain mengeluarkan Gama Amino Butyric Acid (GABA) yang berfungsi menghambat hantaran impuls listrik dari satu neuron ke neuron lainnya oleh neurotransmitter di dalam sinaps.

Selain itu, midbrain juga mengeluarkan enkepalin dan beta endorfin. Zat tersebut dapat menimbulkan efek analgesia yang akhirnya mengeliminasi neurotransmitter rasa nyeri pada pusat persepsi dan interpretasi sensorik somatic di otak. Sehingga efek yang bisa muncul adalah nyeri berkurang (Guyton \& Hall, 2014). Pengaruh terapi murottal dalam menurunkan nyeri didukung oleh haisl penelitian (Sodikin, 2012) tentang Pengaruh Terapi Bacaan Al-Quran (TBA) Melalui Media Audio terhadap Respon Nyeri Pasien Post Operasi Hernia di RS Cilacap. Hasil dari penelitan diperoleh ada perbedaan skala nyeri $(p=0,008 ; \alpha=0,05)$ sebelum dan sesudah TBA.

Sementara itu kompres dingin bekerja dengan mekanisme stimulasi kulit. Terapi kompres dingin menginduksi anestesi lokal, efek tersebut disebut sebagai neurapraxia yang diinduksi dingin, dengan mengurangi ambang aktivasi nosiseptor jaringan dan kecepatan konduktor dari sinyal-sinyal yang mendasari rasa sakit. Hal ini sejalan dengan pendapat (Putra \& Budiarta, 2017) stimulasi kulit dalam mengurangi nyeri adalah dengan meningkatkan pelepasan endorfin yang memblok transmisi stimulus nyeri dan juga menstimulasi serabut saraf yang memiliki diameter besar $\alpha$-Beta sehingga menurunkan transmisi impuls nyeri melalui serabut kecil $\alpha$ Delta dan serabut saraf C. Menurunkan suhu kulit menjadi $4^{\circ}$ Celcius akan mengaktifasi fiberA dan fiber-C yang sensitif terhadap suhu rendah.

Kompres dingin mengurangi suhu kulit dan otot dengan mengurangi aliran darah ke jaringan yang dingin dan mengaktifkan refleks vasokonstriktif simpatis. Proses itu mengurangi edema dan memperlambat pengiriman mediator inflamasi, mengurangi peradangan pada daerah yang terkena, juga mengurangi hipoksia metabolik (Malanga et al., 2015). Terapi kompres dingin menginduksi anestesi lokal, efek tersebut disebut sebagai neuropraksia yang diinduksi dingin, dengan mengurangi ambang aktivasi nosiseptor jaringan dan kecepatan konduktor dari sinyal-sinyal yang mendasari rasa sakit (Putra \& Budiarta, 2017). Hasil penelitian mendukung penelitian (Watkins et al., 2014) mengenai Ice Packs Reduce Postoperative Midline Incision Pain and Narcotic Use: A Randomized Controlled Trial. Hasil penelitian diperoleh ada perbedaan antara nyeri pasca operasi keolpok intervensi sebelum dan setelah intervensi $(p$-value $=0.001<0,05)$.

Terapi kompres dingin dan terapi murotal juga sama-sama bekerja menggunakan teori gate control. Kompres dingin bekerja dengan mekanisme rangsangan kulit sedangkan murottal melalui distraksi atau pengalihan perhatian dengan mendengarkan murottal. Teori gate control (gerbang nyeri) menjelaskan bagaimana pengalihan perhatian (distraksi) dapat mengurangi nyeri, sedangkan pemusatan perhatian terhadap suatu rangsangan nyeri dapat menyebabkan nyeri semakin terasa. Gating juga terjadi pada stimulasi saraf perifer ke korda spinalis. Apabila reseptor taktil kulit $\mathrm{A} \beta$ besar dirangsang bersamaan dengan saat serat $A \delta$ dan $\mathrm{C}$ menyalurkan rangsang nyeri maka pengaktivan traktus neospinotalamikus dan paleospinotalamikus akan berkurang. Hal ini tampaknya disebabkan oleh hambatan lateral sel-sel spina dorsalis oleh reseptor kulit $\mathrm{A} \beta$ (Winarsih, 2018).

Kompres dingin efektif menurunkan nyeri post operasi karena dengan kompres dingin ini menyebabkan transmisi nyeri tertutup sehingga cortex cerebri tidak dapat menerima sinyal karena nyeri sudah diblok dengan stimulasi dingin yang mencapai otak lebih dulu. Hal ini berkaitan dengan gate control theory dimana stimulasi kulit berupa kompres dingin dapat mengaktivasi 
transmisi serabut saraf sensorik A-beta yang lebih besar dan lebih cepat, sehingga menutup gerbang dan menurunkan transmisi nyeri melalui serabut $\mathrm{C}$ dengan diameter yang kecil (Potter et al., 2013).

\section{SimPULAN DAN SARAN}

Berdasarkan hasil penelitian dan pembahasan maka dapat ditarik kesimpulan yaitu: pasien post operasi laparatomi di RSI Fatimah Cilacap sebelum diberikan terapi murrotal mempunyai respon nyeri rata-rata 6,26 dan sesudah diberikan terapi murrotal mempunyai respon nyeri rata-rata 4,66 ; sebelum diberikan terapi kompres dingin mempunyai respon nyeri rata-rata 6,33 dan sesudah diberikan terapi kompres dingin mempunyai respon nyeri rata-rata 4,80; terdapat perbedaan respon nyeri sebelum dan sesudah diberikan terapi murrotal ( $\mathrm{pv}=0,0005)$; terdapat perbedaan respon nyeri sebelum dan sesudah diberikan terapi kompres dingin $(\mathrm{pv}=0,0005)$; tidak terdapat perbedaan respon nyeri sebelum diberikan terapi murrotal dan kompres dingin $(\mathrm{pv}=0,852)$; tidak terdapat perbedaan respon nyeri sesudah diberikan terapi murrotal dan kompres dingin ( $\mathrm{pv}=0,251)$.

Saran yang direkomendasikan kepada perawat pada setiap pelayanan keperawatan khususnya dalam menangani pasien post operasi laparatomi dapat memberikan terapi Murrotal atau terapi kompres dingin pada pasien post operasi laparatomi sebagai terapi komplementer dalam menangani nyeri pada pasien post operasai laparatomi yang murah biaya.

\section{DAFTAR PUSTAKA}

[1] Amelia, W., \& Saputri, D. . (2020). Efektifitas Hand Massage Terhadap Skala Nyeri Pada Pasien Post Operasi Laparatomi di RS. DR. Reksodiwiryo Padang. Jurnal Kesehatan MIDWINERSLION, 5(1).

[2] Anwar, T., Warongan, A. W., \& Rayasari, F. (2020). Pengaruh Kinesio Taping Terhadap Tingkat Nyeri Pada Pasien Post Laporatomi Di Rumah Sakit Umum Dr Dradjat
Prawiranegara, Serang-Banten Tahun 2019. Journal of Holistic Nursing Science, Vol. 7(1), 71-87.

[3] Aryanti, M. I. ., \& Bahtiar, H. (2015). Efektivitas Pemberian Terapi Murotal Terhadap Penurunan Tingkat Kecemasan Pada Pasien Pre Operasi Fraktur di Ruang Kemuning Rumah Sakit Umum Provinsi (RSUP) NTB. Jurnal Ilmiah Kesehatan STIKES Yarsi Mataram, 4, 25.

[4] Asiyah, S. N., \& Istikhomah, I. (2019). Effectiveness of Murottal Therapy in Reducing Anxiety in Diabetics. Journal of Health Science and Prevention, 3(2), 118-121.

[5] Geraldina, A. . (2017). Terapi Musik: Bebas Budaya atau Terikat Budaya? Buletin Psikologi ISSN: 0854-7108 2017, Vol. 25, No. 1. 45-53.

[6] Guyton, A. C., \& Hall, J. E. (2014). Buku Ajar Fisiologi Kedokteran (12th ed.). EGC.

[7] Herrera, E., Sandoval, Maria, C., Camargo, Diana, M., \& Salvini, Tania, F. (2010). Motor and Sensory Nerve Conduction Are Affected Differently by Ice Pack, Ice Massage, and Cold Water Immersion. Physical Therapy, Volume 90(Issue 4), 581591.

https://doi.org/https://doi.org/10.2522 /ptj.20090131

[8] Iryanto, N. (2019). Pengaruh Kombinasi Kompres Dingin dan Murrotal Terhadap Respon Nyeri Pasien Post Operasi Mayor di Bangsal Bedah RSUD Cilacap. Skripsi. Sekolah Tinggi Ilmu Kesehatan (STIKES) Al-Irsyad AlIslamiyyah Cilacap.

[9] Kristanto, A., \& Arofiati, F. (2016). Efektifitas Penggunaan Cold Pack Dibandingkan Relaksasi Nafas Dalam untuk Mengatasi Nyeri Pasca Open Reduction Internal Fixation (ORIF). Indonesian Journal of Nursing Practice, 1(1).

[10] Malanga, G., Yan, N., \& Stark, J. (2015). Mechanisms and efficacy of 
heat and cold therapies for musculoskeletal injury. Postgrad Med. 2015 Jan;127(1):57-65. Doi: 10.1080/00325481.2015.992719.

Epub 2014 Dec 15. PMID: 25526231.

[11] Marliyana. (2018). Pemberian Terapi Murotal Qur'an Terhadap Nyeri Saat Perawatan Luka Post OP Laparotomi di Ruang Kutilang RS.Dr.H.Abdul Moeloek Provinsi Lampung. Jurnal Kesehatan Panca Bhakti Lampung, VI(2).

[12] Novita, D. (2012). Pengaruh Terapi Musik Terhadap Nyeri Post Operasi Open Reduction And Internal Fixation (Orif) Di RSUD Dr. H. Abdul Moeloek Propinsi Lampung, Tesis,. Fakultas Ilmu Perawatan, Program Pascasarjana Magister Ilmu Keperawatan Kekhususan Keperawatan Medikal Bedah, Universitas Indonesia, Depok.

[13] Potter, P. A., Perry, A. G., Stockert, P. A., \& Hall, A. M. (2013). Fundamentals of nursing. (8th ed.). Elsevier Mosby.

[14] Putra, K. K., \& Budiarta, I. G. (2017). Nosiseptor: Klasifikasi dan Fisiologi, Artikel Kepaniteraan Klinik Madya. Univesitas Udayana dan RSUP Sanglah Denpasar.

[15] Smeltzer, S. C., \& Bare, B. G. (2017). Buku Ajar Keperawatan MedikalBedah Brunner \& Suddarth. (12th ed.). EGC.

[16] Sodikin. (2012). Pengaruh Terapi Bacaan Al-Quran Melalui Media Audio terhadap Respon Nyeri Pasien Post Operasi Hernia di RS Cilacap.
Universitas Indonesia.

[17] Susanto, Y. P. P. (2015). Pengaruh Mendengarkan Surat Ar-Rahmaan Terhadap Nyeri Ibu Bersalin di Puskesmas Jumpandang Baru dan Puskesmas Batua Kota Makasar. Tesis. Universitas Hasanuddin, Makasar.

[18] Talu, Y. H. I., Maryah, V., \& Andinawati, M. (2018). Perbedaan Efektifitas Kompres Dingin Dan Kompres Hangat Terhadap Penurunan Intensitas Nyeri Pada Pasien Post Operasi Appendicitis di RSUD Waikabubak Sumba Barat NTT. Nursing News, 3(1).

[19] Watkins, A. A., Johnson, T. V, Shrewsberry, A. B., Nourparvar, P., Madni, T., Watkins, C. J., Feingold, P. L., Kooby, D. A., K Maithel, S., A Staley, C., \& A Master, V. (2014). Ice packs reduce postoperative midline incision pain and narcotic use: a randomized controlled trial. Journal of the American College of Surgeons . J Am Coll Surg. 2014 Sep;219(3):511-7. Doi: 10.1016/j.Jamcollsurg.2014.03.057. Epub 2014 May 23. PMID: 25081937.

[20] Winarsih, G. (2018). Perbedaan efektifitas pemberian terapi murrotal dengan terapi musik klasik terhadap skala nyeri pasien post operasi Fibroadenoma mammae (FAM) di RSUD Cilacap tahun 2018. Skripsi. Program Studi S1 Keperawatan. Sekolah Tinggi Ilmu Kesehatan (STIKES) Al-Irsyad Al-Islamiyyah Cilacap. 